\title{
ZuZANNA TOPOLIŃSKA
}

\section{Partykuły werbalne - ich miejsce i rola w systemie języka}

A b s t r a k t: Autorka wyjaśnia potrzebę uznania partykuł werbalnych za osobną klasę tzw. części mowy, której główną funkcją jest kontrolowanie propozycji modalnych oraz sygnalizowanie różnych trybów.

Słow a klucze: gramatykalizacja; prepozycja; postpozycja; marker kategorialny

0. Przedmiotem analizy i opisu w tym tekście jest klasa wyrazów ${ }^{1}$, która o ile mi wiadomo - nie doczekała się dotąd, przynajmniej na gruncie slawistycznym, uznania, nazwania i opisu jako klasa. Przyjęty przeze mnie termin partykuły werbalne nawiązuje do spotykanego tu i tam w literaturze profesjonalnej traktowania poszczególnych jednostek tej klasy jako partykuł, a zarazem podkreśla różnicę między nimi i partykułami jako klasą predykatów. Partykuły werbalne to w moim rozumieniu zgramatykalizowane markery kategorialne obsługujące poszczególne kategorie gramatyczne charakteryzujące verbum/czasownik jako tzw. część mowy (pars orationis).

$\mathrm{W}$ analizie posługuję się przede wszystkim materiałem dwu najbliższych mi języków, polskiego i macedońskiego. Tytułem wstępu przykładowo wyli-

${ }^{1}$ Wyraz rozumiem tu jako jednostkę języka między dwiema pauzami w tekście pisanym. 
czam tutaj jednostki, które należą do opisywanej przeze mnie klasy: pol. by, $\dot{z} e$, niech..., mac. ќе, би, да, дека, нека, ајде... Fenomen partykuł werbalnych jest szerzej obecny i głębiej wbudowany w strukturę języka w języku macedońskim niż w polszczyźnie, toteż partykułom macedońskim przysługuje pierwszeństwo $\mathrm{w}$ opisie.

\section{Mac. ̌́e}

Macedońskie ḱe gramatykalizuje informację o następstwie zdarzeń na osi czasu, informuje, że zdarzenie nazwane w konstrukcji kontrolowanej przez א́e: 1a. funkcjonuje jako futurum, tj. zrealizuje się po momencie mówienia, por. np.: Ке дојдам утре, 1b. funkcjonuje jako poprzednik realnego kondycjonalu, por. np.: Ḱ дојдам, ако ми време дозволи, albo też 2. funkcjonuje jako poprzednik irrealnego kondycjonalu, por. nр.: Ḱе дојдев, да не ме спречи ураганот. W pierwszych dwu wypadkach ќe kontroluje formy praesentis, w trzecim - formy imperfecti.

Macedońskie א́e jest derywatem prasłowiańskiego rdzenia *xъt- 'chcieć, pragnąć, życzyć sobie' i ma ekwiwalenty formalne i funkcjonalne tego samego pochodzenia w sąsiednich językach południowo-słowiańskich: serbskim, chorwackim i bułgarskim, jednak jedynie w macedońskim języku standardowym i w znacznej części dialektów macedońskich jest nieodmienne, tj. proces jego przekształcania $\mathrm{z}$ verbum w partykułę werbalną został tam zakończony.

Polskim odpowiednikiem macedońskich א́e-konstrukcji są (a) konstrukcje złożone z paradygmatu praesentis predykatu 'być' i infinitiwu koniugowanego czasownika w aspekcie kontynuatywnym, oraz (b) w aspekcie momentalnym - odpowiednie formy aspektowe koniugowanych czasowników.

\section{Pol. by, mac. $\sigma u$}

Pol. by, mac. би kontynuuje stary optatiw prasłowiańskiego czasownika *byti, przy czym na gruncie macedońskim jest to skostniała nieodmienna partykuła werbalna - stara forma 3 os. sg., podczas gdy w polszczyźnie by wypracowało dwa pełne paradygmaty osoby i liczby w funkcji odpowiednio protasis i/lub apodosis kondycjonalu realnego lub irrealnego, przy czym za- 
leżnie od kontekstu i przyjętych zasad linearyzacji by pojawia się w prepozycji lub w postpozycji względem participium praeteriti activi, tj. nazwy czynności, o której mowa, por. np. mac. Јас би дошла. / Дошла би ако најдам време.; Јас би била дошла, да имав време. / Била би дошла, да имав време., pol. Przyszłabym, jeżeli będę miała czas / Ja bym przyszła, jeżeli będę miała czas.; Przyszłabym była, gdybym (była) miała czas. / Ja bym była przyszła, gdybym (była) miała czas. itp.

By w irrealu pojawia się w utartym zestawie z gdy: gdybym, gdybyś...

O zestawieniu żeby por. niżej.

Specjalnego komentarza wymaga złożona partykuła oby! - nawiązanie do starego znaczenia optatiwu, a zarazem dowód, że by bywa wykładnikiem „nowego" optatiwu.

W odpowiednich okolicznościach i mac. $\sigma u$ może samodzielnie konstytuować propozycję. Wyobraźmy sobie np. że w gronie kilku osób pada pytanie: Кој би одел утре на екскурзија? і jeden z obecnych wyraża gotowość: Jas bi..., czy też, pełnym zdaniem: Jас би да одам.

\section{Mac. $\partial a$}

Mac. $\partial a$ wprowadza oratio indirecta po predykatach wolicjonalnych i modalnych, tj. funkcjonalnie odpowiada $+/$ - (a) w 1 os. sg. polskim transformom zdaniowym konstytuowanym przez bezokolicznik, por. nр. Сакам да заминам утре. Chce wyjechać jutro., сzу Сега морам да работам. Teraz musze pracować. itp., (b) w pozostałych formach paradygmatu osoby - polskim konstrukcjom z zestawieniem żeby, por. Сакам да заминеш ympe. $\sim$ Chce, żebyś wyjechat jutro. itd.

Да pojawia się również w 2 os. pl. imperatiwu, por. Аjде, да отиме! itp. Por. także, z odcieniem groźby, w 2 os. sg. i pl. imperatiwu: Да не си отишол таму! 'Nie śmiesz tam pójść! / Żebyś mi tam nie chodził!', Да не сте отииле таму! 'Nie śmiecie tam pójść! / Żebyście mi tam nie chodzili!'.

Konstrukcje z da występują też w funkcji optatywnej, por. np. Само веќe да дојде пролет! 'Żeby tylko już przyszła wiosna!' itp. 


\section{4. Мас. дека}

Мас. дека to swego rodzaju kalka greckiego pou wzmocniona emfatyczną „końcową"² partykułą - $\kappa a$. Element $\partial e$ - to uproszczona prasłowiańska forma zaimkowa *kbde 'gdzie'.

Дека wprowadza oratio indirecta po predykatach mentalnych, po tzw. predykatach mówienia, po predykatach wyrażających emocje... i +/- odpowiada w tej funkcji polskiemu że.

\section{Pol. że}

Pol. że to pierwotna emfatyczna partykuła końcowa potwierdzająca adekwatność wyrażanej oceny zdarzenia i/lub jego uczestników. Do dziś dnia świadczą o tym wyrażenia jak także, wszakże, jakoże..., onże, tenże, tamże..., czy - przy wygłosie samogłoskowym pierwszego elementu - też, również, przecież... ${ }^{3}$

Dzisiaj $z e$ to partykuła werbalna wprowadzająca oratio indirecta - ekwiwalent macedońskiego дека, por. Widzę, że czytasz. Гледам дека читаш.; Proszę cię, żebyś czytat. Те молам да читам. itp.

\section{Pol. niech, mac. нека}

Obie partykuły, i polska, i macedońska, mogą - zależnie od okoliczności wyrażać życzenie, prośbę lub rozkaz.

Życzenie (a) może być skierowane do konkretnego adresata, ale może też (b) wyrażać pragnienie nadawcy przekazu bez określonego adresata, por. ad (a) pol. Niech wam sprzyja pogoda na tym urlopie., тас. Нека Ви е среќен nрестојom!, ad (b) pol. Niech tylko wreszcie przyjdzie wiosna!, тас. Нека завриат испитите, па ќе видиме.

2 Nie znajduję lepszego określenia dla końcowych morfemów typu -ка, -де, -зи..., które nadają zabarwienie emocjonalne wybranym wyrazom, najczęściej pronominom.

3 Jak się wydaje, tutaj należą także macedońskie wtórnie ubezdźwięcznione еднаш czy тогаи. 
Prośba i rozkaz ex definitione mają określonego adresata, przy czym często partykuły nіеch / нека bywają poprzedzone przez jedno eksplicytne proszę / молам, różnica między nimi często zależy od stosunku wzajemnego i pozycji socjalnej nadawcy i adresata przekazu, por. np. pol. Prosze, niech pan przejrzy te dokumenty., тас. Ве молам, прегледајте ги овие документи. to prośba, którą student może skierować do profesora lub szef do podwładnego mu urzędnika.

Niekiedy partykuły niеch i нека mogą nadawać odpowiedniej propozycji znaczenie koncesywne, por. np. pol. Niech się pali, niech się wali, a my będziem świętowali., czy mac. Нека прави како сака а јас ке го напрањам тоа на мој начин. itp.

Wreszcie wypada wspomnieć konwencjonalne formuły okolicznościowe, jak staropolskie powitanie: Niech będzie pochwalony..., czy współczesne: Prosze, niech Państwo pozwola... itp.

\section{Pol. chyba, jakoby, może, zapewne..., mac. божем}

Tryb w służbie modalności epistemicznej, w literaturze przedmiotu znany jako inferentialis, imperceptivus, mediativus....; jego wykładnikiem formalnym są w języku macedońskim odpowiednie formy koniugowanego czasownika, konkretnie - formy starego participium praesentis activi $\mathrm{z}$ formantem -л-, ew. partykuły, jak божем.

Podane partykuły oraz formy imperceptiwu niosą informację, że nadawca przekazu ma wątpliwości co do prawdziwości zdarzenia, o którym mowa.

\section{Mac. ajde!}

Jest to partykuła hortatywna wyrażająca zachętę do wykonania danej czynności, por. np. Ајде да одиме!, Ајде, да им го предложиме овој проект! itp. Jej obecność w systemie pozwala postulować obecność w macedońskim specjalnego trybu, hortatiwu. Ajde! to zarazem jedyna partykuła werbalna zdolna pełnić funkcję samodzielnego predykatu. 


\section{Wnioski}

Opisałam w tym tekście serię wyrażeń / jednostek języka, które - o ile mi wiadomo - nie były dotychczas interpretowane jako klasa. Kryterium wyboru była semantyka i morfosyntaksa tych wyrażeń, tj. fakt, że stanowią one - w moim pojęciu - zgramatykalizowane wykładniki poszczególnych elementów paradygmatu semantycznego (i formalnego) gramatycznej kategorii trybu.

Wszelki przekaz językowy ma określony cel i stanowi transfer określonej informacji. O celu transferu i charakterze przenoszonej informacji informuje nas gramatyczna kategoria trybu. W językach, które mnie tutaj interesują, paradygmat tej kategorii przedstawia się jak następuje:

1. Przekaz może mieć charakter neutralny, bez zabarwienia modalnego, a jedynym jego celem jest dotarcie do uszu zainteresowanych. $W$ ten sposób możemy przekazywać informację o zdarzeniach przeszłych lub aktualnych w momencie mówienia. Tryb, który niesie taki przekaz, to INDICATIVUs;

2. Przekaz w służbie modalności deontycznej ma na celu nakłonienie adresata, aby podjął jakąś aktywność. Tryb, który niesie taki przekaz, to IMPERATIVUS lub HORTATIVUS.

3. Adresat może przyjąć polecenie, ale też ma prawo postawić swoje warunki. Tryb, w którym je formułuje, to KONDYCJONALIS REALIS - sformułowanie warunku, który umożliwi spełnienie polecenia w przyszłości, albo IRREALIS - wyjaśnienie, dlaczego, przy braku realizacji warunku, nie zostało spełnione polecenie w przeszłości; i tu jesteśmy w granicach pola funkcjonalnego modalności deiktycznej.

4. Przekaz w służbie modalności epistemicznej- może zawierać zastrzeżenie, że nadawca nie jest pewien, czy przekazywana informacja jest prawdziwa. Gramatykalizacji takiego przekazu służy, obok odpowiednich partykuł, specjalny tryb: IMPERCEPTIVUS.

5. Przekaz może obejmować dwie zhierarchizowane propozycje, z których linearnie druga - podporządkowana - przenosi tzw. oratio indirecta, tj. mentalną ocenę sytuacji z pozycji nadawcy lub dowolnego innego subiektu; tryb, który gramatykalizuje taką ocenę to SUBJUNCTIVUS. 
W interesujących mnie tutaj językach we wszystkich wymienionych trybach, z wyjątkiem indicatiwu i - w języku macedońskim - imperceptiwu, gramatycznym powierzchniowym wykładnikiem trybu są partykuły werbalne.

\section{Verbal particles - their place and role in the language system ( sum mary)}

The author explains the need of recognizing the existence of verbal particles as a distinct class of the so-called partes orationis, whose main function is controlling modal propositions and signalizing different moods.

Ke y w ord s : grammaticalization; preposition; postposition; categorial marker 
